\title{
NEGATIVE VALUES IN DEA: EXAMINATION OF THE RELATIONSHIP BETWEEN ECONOMIC GROWTH RATES AND AIRLINE PERFORMANCES
}

\author{
Asst. Prof. Dr. Burak KESKIN \\ Cankiri Karatekin University, FEAS, (burakkeskiin@gmail.com) \\ Asst. Prof. Dr. Efehan ULAŞ* \\ Cankiri Karatekin University, Faculty of Science, (efehanulas@karatekin.edu.tr) \\ Res. Asst. Günal BILLEK \\ Bitlis Eren University, Faculty of Science, (gunal-34@hotmail.com)
}

\begin{abstract}
The main goal of this study is to determine whether there is a relationship between the economic growth rates and the performances of airline companies. From this point of view, Data Envelopment Analysis (DEA) is applied to star alliance member airlines for a period of 2012-2014. Firstly, the technical, pure technical and scale efficiency scores were calculated. Then, airlines are divided into four regional groups as America, Europe, Asia and Africa in order to determine the most efficient region. Further, countries economic growth rates which the airline is located are analyzed to support DEA results. Finally, Asia group is found as the most efficient airline group.
\end{abstract}

Keywords: Technical Efficiency, Data Envelopment Analysis, Airline Industry.

\section{DEA'DA NEGATİF DEĞERLER: HAVAYOLU PERFORMANSLARI VE EKONOMIK BÜYÜME ORANLARI ARASINDAKİ İLIŞKINIIN INCELENMESI}

\begin{abstract}
ÖZET
Bu çalışmanın genel amacı, ülkelerin ekonomik büyüme oranları ile o ülkede yer alan havayolu şirketlerinin performansları arasında bir ilişki olup olmadı ğını belirlemektir. Buradan hareketle, Star Alliance üyesi havayolu şirketlerinin 2012-2014 yılları arasindaki verileri üzerinde bir Veri Zarflama Analizi gerçekleştirilmiştir. Öncelikle, her bir havayolu şirketinin teknik ve ölçek etkinlikleri hesaplanmıştır. Daha sonra, havayolu şirketlerinin yer

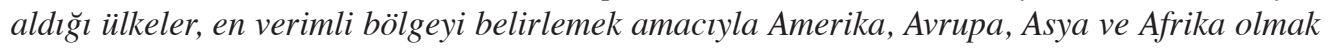
üzere dört grup altında toplanmıştır. Veri Zarflama Analizi sonuçlarını destekleyebilmek ve verimlilik ile büyüme oranları arasında bir iliski bulabilmek adına her bir ülkenin ekonomik büyüme oranları hesaplanmıs ve sonuç olarak en verimli ve en yüksek büyüme oranına sahip bölge Asya bölgesi olmuştur.
\end{abstract}

Anahtar Kelimeler: Teknik Etkinlik, Veri Zarflama Analizi, Havayolu Endüstrisi.

\footnotetext{
* Corresponding Author

www.ijmeb.org ISSN:2147-9208 E-ISSN:2147-9194

http://dx.doi.org/10.17130/ijmeb.2018239939

Başvuru Tarihi: 30.01.2017, Yayına Kabul Tarihi: 08.01.2018
} 


\section{Introduction}

The competitive nature of the airline industry has become more intense in recent years. As the competitiveness intensifies, the ability of the firms within the industry to withstand extended periods of productive inefficiency diminishes. Those firms with lower level of efficiency are likely to feel the impact economic dynamics more severely. The concept of efficiency here is the capability of a unit in utilizing input to produce output. The accessibility within the international airport industry somewhere helps define the access to goods, people, information, ideas and global flows of capital. Since Southeast Asian economies have become increasingly international in orientation since the late 1960s, governments in the region were generally looking for better accessibility within international transportation systems, and in particular the international airline industry. Various means have been employed to influence the development of airline networks in the region, including airline competition policy, stateowned airlines and airport infrastructure investments. These developments may help the economic growth of such countries.

Recent studies on airline performance appraisal focuses on operational performance, neglecting the financial performance that directly impacts the survival of an airline. For example, the current rate and debt ratio used to measure a company's short-term liquidation and long-term payment costs, the provision of assets used to assess the efficiency of assets is crucial for overall business evaluation (Feng \& Wang, 2000:133-142). Hence, the loss of these large budget companies will have a negative impact on the economic growth of the country to which they are affiliated. Most previous studies concerning economic growth focus merely on other factors such as human development index, technological development, natural resources and so on (Ulas \& Keskin, 2017:61-70). However, the relationship between airlines performance and economic growth has not been investigated.

In order to support trade oriented economic development, airline authorizes have increasingly been under pressure to improve airline efficiency to internationally competitive basis. For that reason, this study aimed to demonstrate efficient airline companies and the ways to improve their works are recommended for the inefficient ones.

\section{Literature Review}

There are many studies in literature related to efficiencies of airline companies. But none of them investigated the relationship between countries economic growth rates and airline companies' efficiency. This is the main scope of this study.

Most previous studies have examined the relationship between air transport development and economic growth in one of these two perspectives: the demand side and the production side. On the demand side, economic growth is considered to be a vital factor in assessing future air travel demand. On the other hand, some studies focused on the efficiency of airline companies and airports. Several of those studies are shown as follow:

Lin \& Hong (2006:342-351), used DEA to assess the operational performance of 20 major airports around the world. They found that the form of ownership and the size of an airport are not apparently correlated with operational performance of airports. But, for a hub 
airport, it is found that the location of the airport and the economic growth rate of the country which the airport is located are all related to the operational performance of airports.

Fleming \& Ghobrial (1994:37-44) have developed a total demand model that relates total annual passenger targets to certain economic activities, including population and per capita income. Empirical results showed that there is a strong correlation between air navigation demand and economic variables.

Barros \& Dieke (2007:184-191), addressed empirically financial operational performance of Italian airports using DEA. With panel data for 2001-2003, the study tested variable relationship-the relative roles of dimension, managerial status and workload unit-to measure proximity of the airports to the frontiers of best practices.

Yao \& Yang (2012:318-329) used panel data in China to identify key determinants of air transport. The results showed that air transport is positively related to economic growth.

Gladovic et al., (2012:7423-7430) investigated airlines business efficiency using data envelopment analysis. They had used input oriented data envelopment analysis and considered available seat kilometer, available tone kilometer and number of employees as inputs, number of passengers, revenue passenger kilometer, revenue tone kilometer, passenger load factor, total load factor, revenue and profit as outputs. They had found efficient nine companies of eleven.

Button \& Taylor (2000:209-222) used employment as an economic development variable and examined the effects of international air transport. Brueckner (2003:1455-1469) examined the link between airline traffic and employment in US metropolitan areas; the results showed that a $10 \%$ increase in passenger fleets in a metropolitan area resulted in an increase of about $1 \%$ in service-related industries.

Ulas \& Keskin (2017:335-345) applied TOPSIS and DEA in order to investigate the effect of privatization and deregulation strategies on performance of European busiest twenty airports.

Kopsch (2012:46-48) analyzed the demand model for indoor air navigation in Sweden, which, as an independent variable, affects GDP's domestic demand for air navigation positively.

Rai (2013:38-45) measured efficiency of twenty airlines with DEA. Rai had employed output oriented data DEA and he had selected as inputs that number of planes, number of employees and gallons of fuels consumed. He had selected as outputs that revenue passenger miles, number of departures, number of passengers and available ton-miles. Po-Lin Lai (2013), studied efficiencies of 24 airports which located Europe and Asia-Pacific via DEA, DEA-AHP and DEA-AHP/AR. He intended to determine that private or public operated airports are more efficient using DEA. End of the research he found that private operated airports is little more efficient but this is not statistically significant. Liebert \& Niemeier (2013) provide literature review on different methods for efficiency measure including DEA and SFA. They showed the most efficient parameters that have been used so far which are traffic composition, competition of airline companies, use of source and events that are not related to aeronautic. 
Mukkala \& Tervo (2013:1508-1520) used a panel of Granger non-densitization techniques to examine the relationship between air transport and regional economic performance based on annual data from 86 regions and 13 European countries in the period 1991-2010. The results show that the causality processes are homogenous in the air traffic in the environmental regions without regional growth, but are not homogeneous in the core regions.

\section{Methodology}

\subsection{Data Envelopment Analysis}

DEA approach is employed in this study to measure the efficiency of airlines. The idea of efficiency measurement was developed by Farrel. (Farrel, 1957). This measurement was later expanded by Charnes (Charnes et al., 1978). They called the technique as Data Envelopment Analysis (DEA) (Gladovic et al., 2012:7424).

In DEA model, researchers need to formulate the problem into mathematical expression. The mathematical formulation of DEA consists in the solution of a set of linear programming models (Charnes, et al., 1978) aimed at maximizing the efficiency of each DMU (Decision Making Unit). The DEA mathematical model is as follows:

$$
\operatorname{Maxh}_{j}=\frac{\sum_{r=l}^{n} u_{r} y_{r}}{\sum_{i=l}^{m} v_{r} x_{r}}
$$

Where, $h_{j}$ is effectiveness of $j$. decision-making unit. The goal should be maximization of $h_{j}$. Constrains can be shown as follow:

$$
\begin{aligned}
& \frac{\sum_{r=l}^{n} u_{r} y_{r}}{\sum_{i=l}^{m} v_{r} x_{r}} \leq 1 \\
& u_{r} \geq 0 \\
& v_{i} \geq 0
\end{aligned}
$$

Where, $n, m, u_{n} y_{n}, v_{m}, x_{m}$ show output number, input number, weight of $n$. output, amount of $n$. output, weight of $m$. input and amount of $m$. input respectively. For $\mathrm{j}=1,2, \ldots, \mathrm{S}$. where $\mathrm{S}$ is number of DMUs.

While CCR model is suitable for industries that show a constant return to scale, BCC model is suitable for industries that show a variable return to scale such as airline industry. From this point of view, in this study the original Banker, Charnes and Cooper (BCC) model was employed. 
The CRS (Constant Return to Scale) efficiency score shows Technical Efficiency (TE) which measures inefficiency. Additionally, VRS (Variable Return to Scale) efficiency scores show Pure Technical Efficiency (PTE), that is, a measure of efficiency without Scale Efficiency (SE). It is possible to decompose TE into PTE and SE. SE can be calculated by dividing TE to PTE (Avkiran, 2001:67). The relationship, SE = OTE /PTE, provides a measure of scale efficiency.

The "Technical Efficiency (TE)" term defines as ability of a firm to produce maximum output with a given set of inputs or using minimum level of inputs to produce a given level of outputs. Technical efficiency takes a value between 0 and 1 . A value of 1 means that the bank is fully efficient and 0 means that the bank is fully inefficient. For example, a value of TE is 0.80 and this value implies that the bank is efficient at level of $\% 80$ and this bank could have produced same level of output by using $\% 20$ less quantity of input.

\subsection{The Panel Data Used in Study}

Implementation of a model for measuring the efficiency was conducted in twenty-six airlines which are members of Star Alliance organization for the years of 2012, 2013 and 2014. Due to Air India joined in 2015 and Eva Air joined in 2013 to star alliance they are excluded from the data. The panel data is obtained directly from annual reports of airlines and star alliance official website. Therefore, it can be said that the data used in this study is reliable. It is important to note that the deflator is applied to the sales revenues in order to distinguish between changes in sales revenues. Bowlin's method (1998) has been used to remove the negative values that emerged after using the deflator. He suggests this approach because the feature of the DEA models is to put each DMU in the best possible light and thus try to emphasize the outputs that DMU is giving the best performance. Therefore, Bowlin (1998) does not expect an output variable with a very small value to contribute to the high efficiency score, which is valid for a negative value. So that such a translation usually does not adversely affect the score of the activity. However, this means that the value should not be greater than any other output value in the dataset.

For our dataset, the values of the output parameter, sales revenue, became negative after applying the deflator. In order to handle the negative values, we selected numbers that were greater than the minimum variable of the sales revenue and added this value for each variable. For the outputs, we looked at increasing the decreases in mistakes and increasing the decreases in sales revenue, so we arbitrarily added a value of 40 to each at the year 2012 and 50 to each at the year 2013 and 30 to each at the year 2014.

The idea of analyzing an airline alliance appeared because of intended to carry out a cross-country study. That's why star alliance organization members were selected because it is the biggest airline alliance and carrying most passenger airline organization in the world as of 2015. Additionally, this alliance -all around the world- has important airline companies which playing important role in the airline industry. For that reason, it is important to show that whether these airlines are efficient or not. 


\subsection{Input and Output Parameters}

In this study four input and three output parameters were used. Input and output parameters were selected based on a survey literature mentioned at the previous section, a study of annual reports of the airlines and discussion with airline analysts as follows:

Input Parameters: Number of Aircrafts, Number of Airports Served and Number of Employee.

Output Parameters: Number of Annual Passenger, Sales Revenue and Number of Departures.

The panel data for these parameters were collected from annual reports of airlines and Star Alliance organization official website for the years of 2012, 2013 and 2014. The sample of twenty-five airlines represents large carrier over the world. The sample of membership is listed on Table 1.

\section{Table 1: List of Airlines Used in Study}

\begin{tabular}{ccc}
\hline Number & Airlines & Origin \\
\hline $\mathbf{1}$ & Adria Airways & Slovenia \\
$\mathbf{2}$ & Aegean Airlines & Greece \\
$\mathbf{3}$ & Air Canada & Canada \\
$\mathbf{4}$ & Air China & China \\
$\mathbf{5}$ & Air New Zealand & New Zealand \\
$\mathbf{6}$ & All Nippon Airlines & Japan \\
$\mathbf{7}$ & Asiana Airways & South Korea \\
$\mathbf{8}$ & Austrian Airlines & Austria \\
$\mathbf{9}$ & Avianca & Colombia \\
$\mathbf{1 0}$ & Brussels Airlines & Belgium \\
$\mathbf{1 1}$ & Copa Airlines & Panama \\
$\mathbf{1 2}$ & Croatia Airlines & Croatia \\
$\mathbf{1 3}$ & Egypt Air & Egypt \\
$\mathbf{1 4}$ & Ethiopian Airlines & Ethiopia \\
$\mathbf{1 5}$ & Lot Polish Airlines & Poland \\
$\mathbf{1 6}$ & Lufthansa & Germany \\
$\mathbf{1 7}$ & Scandinavian Airlines & Sweden \\
$\mathbf{1 8}$ & Shenzhen Airlines & China \\
$\mathbf{1 9}$ & Singapore Airlines & Singapore \\
$\mathbf{2 0}$ & South African Airlines & South Africa \\
$\mathbf{2 1}$ & Swiss Air & Switzerland \\
$\mathbf{2 2}$ & Tap Portugal & Portugal \\
$\mathbf{2 3}$ & Tai Airways & Thailand \\
$\mathbf{2 4}$ & Turkish Airlines & Turkey \\
$\mathbf{2 5}$ & United Airlines & USA \\
\hline & & \\
\hline
\end{tabular}

The quantitative relationship between input and output in the emergence of decisionmaking units is very important in terms of the reliability of the research and the validity of the scores obtained. The relationship between the output and input parameters are given in Table 2 . 
Table 2: Correlation Analysis Results Between Input and Output Variables

\begin{tabular}{lcccccc}
\hline & $\begin{array}{c}\text { N. of Air. } \\
\text { Ser. }\end{array}$ & $\begin{array}{c}\text { N.of } \\
\text { Empl. }\end{array}$ & $\begin{array}{c}\text { N.of } \\
\text { Aircraft }\end{array}$ & $\begin{array}{c}\text { Annual } \\
\text { Pass. }\end{array}$ & $\begin{array}{c}\text { Daily } \\
\text { Depart. }\end{array}$ & $\begin{array}{c}\text { Sales } \\
\text { Revenue }\end{array}$ \\
\hline N. of Air. Ser. & 1 & 0,8722 & 0,9091 & 0,9068 & 0,9080 & 0,3924 \\
\hline N. of Empl. & 0,8722 & 1 & 0,9532 & 0,9716 & 0,9468 & 0,3392 \\
\hline N. of Aircraft & 0,9091 & 0,9532 & 1 & 0,9748 & 0,9923 & 0,3580 \\
\hline Annual Pass. & 0,9068 & 0,9716 & 0,9748 & 1 & 0,9833 & 0,3341 \\
\hline Daily Depart. & 0,9080 & 0,9468 & 0,9923 & 0,9833 & 1 & 0,3345 \\
\hline Sales Reven. & 0,3924 & 0,3392 & 0,3580 & 0,3341 & 0,3345 & 1 \\
\hline
\end{tabular}

The current study employed output oriented DEA model for twenty-six airlines which are member of Star Alliance organization for the years of 2012, 2013 and 2014.

\section{Findings}

The software DEAP version 2.1 is used for analysis. The dataset used is this study is suspected that an increase in inputs dose not result in a proportional change in the outputs. So that variable return to scale is suitable for airline industry. In this study, only BCC model was employed. For that purpose, firstly, overall technical and pure technical efficiency scores and later scale efficiency scores were computed. These results are given on Table 3, Table 5, Table 7 and referral of clustering analysis of airlines are given on the Table 4, Table 6 and Table 8 for the years of 2012, 2013 and 2014 respectively.

On Table 3, the first column represents the number of airline companies which are given in Table 1 previously. The second column indicates overall technical efficiency scores under Constant Return to Scale (CRS) assumption. The third column shows pure technical efficiency score under Variable Return to Scale (VRS). In last column, scale efficiency scores are given.

As seen on the Table 3, pure technical efficiency contributes more in compared to technical efficiency scores. This is because of that airline industry is more suitable for variable return to scale characteristic. The lowest scale efficiency score is observed by Brussels Airlines. Ethiopian Airlines is found as the worst performing airline and it can be said that Ethiopian Airlines performed worst managerial performance to organize their inputs in the production process.

Table 4 shows the referral frequency for every airport in the BCC model for the year of 2012. The results show that Singapore Airlines has the highest referral frequency (13 times referred). The airports referred the Singapore airlines are Air Canada, Air China, Air New Zealand, Brussels, Copa Airlines, Egypt Air, Ethiopian Airlines, South African Airlines, and Tap Portugal. Lufthansa and Aegean Airlines have the second and third referral frequency with 10 and 11 times respectively. Furthermore, 10 relatively efficient airlines were also referred. Among 12 efficient airports, Singapore Airlines is found as the most relatively efficient airlines. 
Table 3: Efficiency Scores of Airlines for the Year of 2012

\begin{tabular}{|c|c|c|c|c|}
\hline AIRLINES & CRS & VRS & SCALE & \\
\hline 1 & 1 & 1 & 1 & - \\
\hline 2 & 1 & 1 & 1 & - \\
\hline 3 & 0,823 & 0,937 & 0,878 & Drs \\
\hline 4 & 0,596 & 0,723 & 0,825 & Drs \\
\hline 5 & 1 & 1 & 1 & - \\
\hline 6 & 1 & 1 & 1 & - \\
\hline 7 & 0,943 & 1 & 0,943 & Drs \\
\hline 8 & 0,716 & 0,972 & 0,736 & Drs \\
\hline 9 & 0,903 & 0,974 & 0,958 & Drs \\
\hline 10 & 0,517 & 0,931 & 0,555 & Drs \\
\hline 11 & 0,693 & 0,854 & 0,811 & Drs \\
\hline 12 & 1 & 1 & 1 & - \\
\hline 13 & 0,525 & 0,783 & 0,671 & Drs \\
\hline 14 & 0,442 & 0,779 & 0,568 & Drs \\
\hline 15 & 0,953 & 1 & 0,953 & Drs \\
\hline 16 & 1 & 1 & 1 & - \\
\hline 17 & 0,831 & 0,922 & 0,902 & Drs \\
\hline 18 & 0,909 & 0,963 & 0,945 & Drs \\
\hline 19 & 0,959 & 1 & 0,958 & Drs \\
\hline 20 & 0,707 & 0,795 & 0,888 & Drs \\
\hline 21 & 0,870 & 0,917 & 0,949 & Drs \\
\hline 22 & 0,676 & 0,774 & 0,873 & Drs \\
\hline 23 & 0,947 & 1 & 0,947 & Drs \\
\hline 24 & 0,756 & 1 & 0,756 & Drs \\
\hline 25 & 1 & 1 & 1 & - \\
\hline Mean & $\mathbf{0 , 8 3 2}$ & $\mathbf{0 , 9 3 3}$ & $\mathbf{0 , 8 8 5}$ & \\
\hline
\end{tabular}

Table 4: The Referral of Clustering Analysis of 2012

\begin{tabular}{cccccc}
\hline No. & $\begin{array}{c}\text { Referral } \\
\text { Clustering }\end{array}$ & $\begin{array}{c}\text { Referral } \\
\text { Frequency }\end{array}$ & No. & $\begin{array}{c}\text { Referral } \\
\text { Clustering }\end{array}$ & $\begin{array}{c}\text { Referral } \\
\text { Frequency }\end{array}$ \\
\hline $\mathbf{1}$ & 1 & 2 & $\mathbf{1 4}$ & $12,15,19$ & 0 \\
\hline $\mathbf{2}$ & 2 & 11 & $\mathbf{1 5}$ & 15 & 9 \\
\hline $\mathbf{3}$ & $19,16,25,15$ & 0 & $\mathbf{1 6}$ & 16 & 10 \\
\hline $\mathbf{4}$ & $16,25,19,15$ & 0 & $\mathbf{1 7}$ & $25,16,15,2$ & 0 \\
\hline $\mathbf{5}$ & 5 & 0 & $\mathbf{1 8}$ & $16,19,25,2,6$ & 0 \\
\hline $\mathbf{6}$ & 6 & 3 & $\mathbf{1 9}$ & 19 & 13 \\
\hline
\end{tabular}


Table 4 continued

\begin{tabular}{cccccc}
\hline $\mathbf{7}$ & 7 & 2 & $\mathbf{2 0}$ & $2,1,19,16$ & 0 \\
\hline $\mathbf{8}$ & $2,15,25,16,19$ & 0 & $\mathbf{2 1}$ & $2,25,24,16$ & 0 \\
\hline $\mathbf{9}$ & $2,16,19,7,6$ & 0 & $\mathbf{2 2}$ & $2,15,16,19$ & 0 \\
\hline $\mathbf{1 0}$ & $2,1,15,19$ & 0 & $\mathbf{2 3}$ & $2,17,19,6$ & 0 \\
\hline $\mathbf{1 1}$ & $25,16,15,19,2$ & 0 & $\mathbf{2 4}$ & 24 & 1 \\
\hline $\mathbf{1 2}$ & 12 & 1 & $\mathbf{2 5}$ & 25 & 8 \\
\hline $\mathbf{1 3}$ & $2,25,15,19$ & 0 & & & \\
\hline
\end{tabular}

As seen on Table 5, mean pure technical efficiency score is higher than mean technical efficiency score. The lowest scale efficiency score is observed by Austrian Airlines. This result shows that Austrian Airlines used inappropriate size of their source. Air China found as the worst performing airline for the year 2013.

Table 5: Efficiency Scores of Airlines for the Year of 2013

\begin{tabular}{|c|c|c|c|c|}
\hline AIRLINES & CRS & VRS & SCALE & \\
\hline 1 & 1 & 1 & 1 & - \\
\hline 2 & 1 & 1 & 1 & - \\
\hline 3 & 0,864 & 0,899 & 0,961 & Drs \\
\hline 4 & 0,835 & 0,904 & 0,924 & Drs \\
\hline 5 & 1 & 1 & 1 & - \\
\hline 6 & 1 & 1 & 1 & - \\
\hline 7 & 1 & 1 & 1 & - \\
\hline 8 & 0,806 & 0,883 & 0,912 & Drs \\
\hline 9 & 0,868 & 0,885 & 0,981 & Drs \\
\hline 10 & 0,735 & 0,736 & 0,999 & Irs \\
\hline 11 & 0,686 & 0,687 & 0,999 & Irs \\
\hline 12 & 1 & 1 & 1 & - \\
\hline 13 & 0,720 & 0,720 & 0,999 & - \\
\hline 14 & 0,517 & 0,533 & 0,969 & Drs \\
\hline 15 & 1 & 1 & 1 & - \\
\hline 16 & 0,947 & 1 & 0,947 & Drs \\
\hline 17 & 1 & 1 & 1 & - \\
\hline 18 & 0,893 & 0,894 & 0,998 & Irs \\
\hline 19 & 1 & 1 & 1 & - \\
\hline 20 & 0,712 & 0,747 & 0,953 & Irs \\
\hline 21 & 1 & 1 & 1 & - \\
\hline 22 & 0,804 & 0,805 & 0,999 & Irs \\
\hline 23 & 1 & 1 & 1 & - \\
\hline
\end{tabular}


Table 5 continued

\begin{tabular}{ccccc}
\hline 24 & 1 & 1 & 1 & - \\
\hline 25 & 1 & 1 & 1 & - \\
\hline Mean & $\mathbf{0 , 8 9 5}$ & $\mathbf{0 , 9 0 8}$ & $\mathbf{0 , 9 8 6}$ & \\
\hline
\end{tabular}

Table 6: The Referral of Clustering Analysis of 2013

\begin{tabular}{cccccc}
\hline No. & $\begin{array}{c}\text { Referral } \\
\text { Clustering }\end{array}$ & $\begin{array}{c}\text { Referral } \\
\text { Frequency }\end{array}$ & No. & $\begin{array}{c}\text { Referral } \\
\text { Clustering }\end{array}$ & $\begin{array}{c}\text { Referral } \\
\text { Frequency }\end{array}$ \\
\hline $\mathbf{1}$ & 1 & 1 & $\mathbf{1 4}$ & $2,21,19$ & 0 \\
\hline $\mathbf{2}$ & 2 & 6 & $\mathbf{1 5}$ & 15 & 1 \\
\hline $\mathbf{3}$ & $17,21,25,16$ & 0 & $\mathbf{1 6}$ & 16 & 3 \\
\hline $\mathbf{4}$ & $16,21,25,6$ & 0 & $\mathbf{1 7}$ & 17 & 3 \\
\hline $\mathbf{5}$ & 5 & 0 & $\mathbf{1 8}$ & $6,12,7,21,19$ & 0 \\
\hline $\mathbf{6}$ & 6 & 6 & $\mathbf{1 9}$ & 19 & 6 \\
\hline $\mathbf{7}$ & 7 & 2 & $\mathbf{2 0}$ & $6,12,21,1$ & 0 \\
\hline $\mathbf{8}$ & $17,21,15,2$ & 0 & $\mathbf{2 1}$ & 21 & 11 \\
\hline $\mathbf{9}$ & $6,24,21,16,19$ & 0 & $\mathbf{2 2}$ & $6,12,21,2,24,19$ & 0 \\
\hline $\mathbf{1 0}$ & $19,2,21,12,24$ & 0 & $\mathbf{2 3}$ & 23 & 0 \\
\hline $\mathbf{1 1}$ & $2,21,17,19,6,12$ & 0 & $\mathbf{2 4}$ & 24 & 4 \\
\hline $\mathbf{1 2}$ & 12 & 5 & $\mathbf{2 5}$ & 25 & \\
\hline $\mathbf{1 3}$ & $21,24,2,7$ & 0 & & & \\
\hline
\end{tabular}

Table 6 shows the referral frequency for every airport in the BCC model for the 2013. The results of the analyses show that Swiss Air has the highest referral frequency (11 times referred). Aegean, All Nippon and Singapore Airlines have the second highest referral frequency with 6 times. Moreover, 9 relatively efficient airlines were also referred. The result of these analyses indicates that among these 14 efficient airports, Swiss Air is found as the most relatively efficient airlines.

Table 7: Efficiency Scores of Airlines for the Year of 2014

\begin{tabular}{ccccc}
\hline AIRLINES & CRS & VRS & SCALE & \\
\hline $\mathbf{1}$ & 1 & 1 & 1 & - \\
\hline $\mathbf{2}$ & 1 & 1 & 1 & - \\
\hline $\mathbf{3}$ & 0,888 & 0,937 & 0,948 & Drs \\
\hline $\mathbf{4}$ & 0,830 & 1 & 0,830 & Drs \\
\hline $\mathbf{5}$ & 1 & 1 & 1 & - \\
\hline $\mathbf{6}$ & 1 & 1 & 1 & - \\
\hline $\mathbf{7}$ & 1 & 1 & 1 & - \\
\hline $\mathbf{8}$ & 0,791 & 0,892 & 0,887 & Drs \\
\hline $\mathbf{9}$ & 0,827 & 0,874 & 0,946 & Drs \\
\hline
\end{tabular}


Table 7 continued

\begin{tabular}{ccccc}
\hline $\mathbf{1 0}$ & 0,859 & 0,934 & 0,920 & Drs \\
\hline $\mathbf{1 1}$ & 0,669 & 0,810 & 0,826 & Drs \\
\hline $\mathbf{1 2}$ & 1 & 1 & 1 & - \\
\hline $\mathbf{1 4}$ & 0,536 & 0,768 & 0,698 & Drs \\
\hline $\mathbf{1 5}$ & 0,442 & 0,774 & 0,571 & Drs \\
\hline $\mathbf{1 6}$ & 1 & 1 & 1 & - \\
\hline $\mathbf{1 7}$ & 0,968 & 1 & 0,968 & Drs \\
\hline $\mathbf{1 8}$ & 1 & 1 & 1 & - \\
\hline $\mathbf{1 9}$ & 0,924 & 0,944 & 0,979 & Drs \\
\hline $\mathbf{2 0}$ & 1 & 1 & 1 & - \\
\hline $\mathbf{2 1}$ & 0,758 & 0,848 & 0,894 & Drs \\
\hline $\mathbf{2 2}$ & 0,917 & 0,923 & 0,993 & Irs \\
\hline $\mathbf{2 3}$ & 0,784 & 0,928 & 0,844 & Drs \\
\hline $\mathbf{2 4}$ & 1 & 1 & 1 & - \\
\hline $\mathbf{2 5}$ & 0,925 & 0,992 & 0,932 & Drs \\
\hline Mean & 1 & 1 & 1 & - \\
\hline & $\mathbf{0 , 8 8 5}$ & $\mathbf{0 , 9 4 5}$ & $\mathbf{0 , 9 2 9}$ & \\
\hline
\end{tabular}

Similarly, it is found that pure technical efficiency scores are higher than technical efficiency scores for the year 2014. The lowest scale efficiency score is observed by Ethiopian Airlines. Egypt Air is found as the least efficient airline for the year 2014 as seen on the Table 7 under VRS assumption.

Table 8: The Referral of Clustering Analysis of 2014

\begin{tabular}{cccccc}
\hline No. & $\begin{array}{c}\text { Referral } \\
\text { Clustering }\end{array}$ & $\begin{array}{c}\text { Referral } \\
\text { Frequency }\end{array}$ & No. & $\begin{array}{c}\text { Referral } \\
\text { Clustering }\end{array}$ & $\begin{array}{c}\text { Referral } \\
\text { Frequency }\end{array}$ \\
\hline $\mathbf{1}$ & 1 & 1 & $\mathbf{1 4}$ & $12,7,4$ & 0 \\
\hline $\mathbf{2}$ & 2 & 1 & $\mathbf{1 5}$ & 15 & 2 \\
\hline $\mathbf{3}$ & $6,17,25,16$ & 0 & $\mathbf{1 6}$ & 16 & 6 \\
\hline $\mathbf{4}$ & 4 & 4 & $\mathbf{1 7}$ & 17 & 7 \\
\hline $\mathbf{5}$ & 5 & 2 & $\mathbf{1 8}$ & $6,17,16,5,19$ & 0 \\
\hline $\mathbf{6}$ & 6 & 9 & $\mathbf{1 9}$ & 19 & 1 \\
\hline $\mathbf{7}$ & 7 & 3 & $\mathbf{2 0}$ & $6,12,1$ & 0 \\
\hline $\mathbf{8}$ & $17,15,12,6$ & 0 & $\mathbf{2 1}$ & $12,2,6,7,17$ & 0 \\
\hline $\mathbf{9}$ & $16,12,17,5,6$ & 0 & $\mathbf{2 2}$ & $6,12,4,16$ & 0 \\
\hline $\mathbf{1 0}$ & $6,15,12,17$ & 0 & $\mathbf{2 3}$ & 23 & 0 \\
\hline $\mathbf{1 1}$ & $25,16,4,12$ & 0 & $\mathbf{2 4}$ & $6,17,25,16$ & 3 \\
\hline $\mathbf{1 2}$ & 12 & 9 & $\mathbf{2 5}$ & 25 & \\
\hline $\mathbf{1 3}$ & $12,4,7$ & 0 & & & \\
\hline
\end{tabular}


Table 8 shows the referral frequency for every airport in the BCC model for the 2014. The results of the analysis show that All Nippon Airlines and Croatia Airlines has the highest referral frequency ( 9 times referred). Moreover, 10 relatively efficient airlines were also referred. The result of this analyses indicates that among these 15 efficient airports, All Nippon and Croatia Airlines is found as the most relatively efficient airlines.

Mean scores of pure technical efficiency score for the years 2012, 2013 and 2014 are obtained after pure technical efficiency scores are calculated for each airline company. Then, the mean of these scores are calculated to select the most efficient region. As result, Asia region is found as the most efficient region.

Table 9: Regional Mean Efficiency Scores

\begin{tabular}{|c|c|c|c|}
\hline America & Asia & Australia-Africa & Europe \\
\hline $\begin{array}{c}\text { Air Canada } \\
\text { Avianca Airlines } \\
\text { Copa Airlines } \\
\text { United Airlines }\end{array}$ & $\begin{array}{c}\text { Air China } \\
\text { All Nippon Airlines } \\
\text { Asiana Airlines } \\
\text { Shenzhen Airlines } \\
\text { Singapore Airlines } \\
\text { Thai Airlines }\end{array}$ & $\begin{array}{c}\text { Air New Zealand } \\
\text { Egypt Air } \\
\text { Ethiopian Air. } \\
\text { South African Air. }\end{array}$ & $\begin{array}{c}\text { Adria Airways } \\
\text { Aegean Airlines } \\
\text { Austrian Airlines } \\
\text { Brussels Airlines } \\
\text { Croatia Airlines } \\
\text { Lot Polish Airlines } \\
\text { Lufthansa } \\
\text { Scandinavian } \\
\text { Swiss Air } \\
\text { Tap Portugal } \\
\text { Turkish Airlines }\end{array}$ \\
\hline $\begin{array}{c}2012-0,941 \\
2013-0,865 \\
2014-0,905 \\
\text { Mean }-0,904\end{array}$ & $\begin{array}{c}2012-0,948 \\
2013-0,966 \\
2014-0,991 \\
\text { Mean - 0,968 }\end{array}$ & $\begin{array}{c}2012-0,839 \\
2013-0,750 \\
2014-0,848 \\
\text { Mean }-0,812\end{array}$ & $\begin{array}{c}2012-0,956 \\
2013-0,948 \\
2014-0,970 \\
\text { Mean }-0,958\end{array}$ \\
\hline
\end{tabular}

As mentioned in Lin \& Hong (2006)'s study, economic growth rate of a country which the airport or airline company located is one of the most important factors that effects to the operational performance of airline industry for that country. So, in this study mean economic growth rates are computed by utilizing World Bank reports for the years of 2012, 2013 and 2014. It is found that the mean growth rates of the countries which are located in Asia region are higher than the other regions with the growth rate of $4.41 \%$. This result supports to DEA results of this study. Additionally, according to The International Air Transport Association (IATA) 2015 mid-year report, an airline company's profitability improves when economy is strong as shown below on Figure 1.

A strong economic cycle is unambiguously good for airline profitability. Even when fuel prices are high (as in 2010) a strong economy will allow to airline to generate improved profits and returns on capital (IATA Report, 2015). 
Figure 1: The Relationship between Growth Rate and Airline Profitability

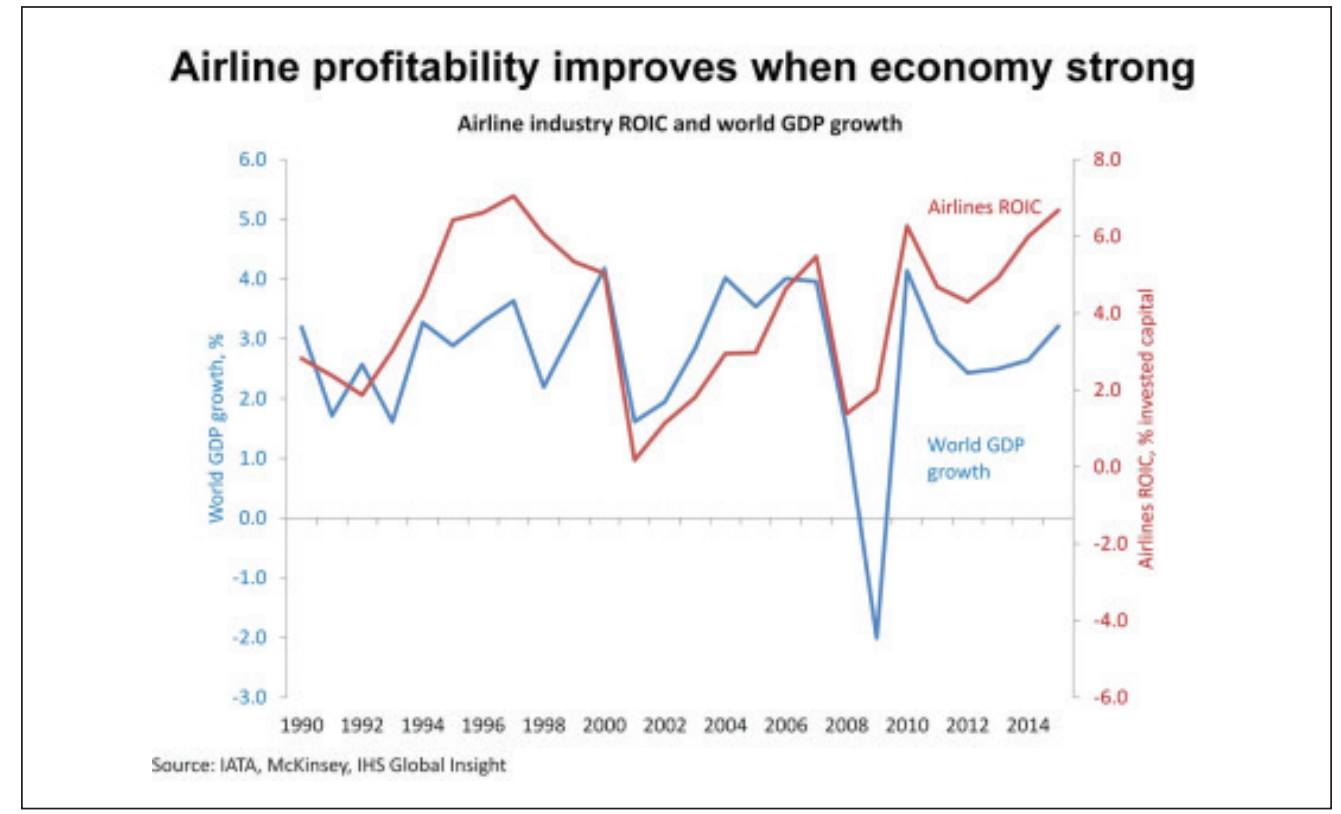

\section{Conclusion}

DEA method has successfully computed the relative efficiencies for the selected airlines which consists the input and output parameters. This paper shows how DEA can be applied as a useful management tool for assessing the efficiencies of airlines. Overall with the DEA method, firstly technical and pure technical efficiency scores of 26 star alliance organization member airlines were investigated for the years of 2012, 2013, 2014 and later by using these scores scale efficiency scores are computed. Secondly, airlines were divided into four regional groups as America, Asia, Africa-Australia, and Europe according to their country origins and Asia group was found the most efficient airline group in this study. Furthermore, World Bank reports were investigated, and each region's economic growth rates are computed. IATA and many studies in past shows that an airline company's efficiency and profitability improve when economy is strong. As a result, it is found that the highest growth rate was observed by Asia countries with $\% 4.41$. Thus, it can be said that the results of this study are consistent with the current literature.

\section{References}

Avkiran, N. K. (2001). Investigating technical and scale efficiencies of Australian universities through data envelopment analysis. Socio-Economic Planning Sciences, 35, 57- 80.

Barros, C., \& Dieke, B. (2007). Performance evaluation of Italian airports: A data envelopment analysis. Journal of Air Transport Management, 13,184-191.

Bowlin, W. F. (1998). Measuring performance: An introduction to data envelopment analysis (DEA). The Journal of Cost Analysis, 15(2), 3-27. 
Brueckner, J. K. (2003). Airline traffic and urban economic development. Urban Studies, 40 (8), 1455-1469.

Button, K., \& Taylor, S. (2000). International air transportation and economic development. Journal of Air Transport Management, 6 (4), 209-222.

Charnes, A. et al. (1978). Measuring the efficiency of decision making units. European Journal of Operational Research, 429-444.

Feng, C. M., \& Wang, R. T. (2000). Performance evaluation for airlines including the consideration of financial ratios. Journal of Air Transport Management, 6 (3), 133-142.

Fleming, K., \& Ghobrial, A. (1994). An analysis of the determinants of regional air travel demand. Transportation Planning and Technology, 18 (1), 37-44.

Gladovic, P. et al. (2012). Quantification of Airlines Business Efficiency Using DEA, African Journal of Business Management, 6 (25), 7423-7430.

IATA (2015). The international air transport association 2015 mid-year report.

Lai, P. (2013). A study on the relationship between airport privatization and airport efficiency. Cardiff: Cardiff University.

Lin, L. C., \& Hong, C. H. (2006). Operational performance evaluation of international major airports: An application of data envelopment analysis. Journal of Air Transport Management, 12, 342-351.

OECD, Retrieved December 31, 2015 from www.oecd.org

Rai, A. (2013). Measurement of efficiency in the airline industry using DEA, Investment Management and Financial Innovation, 10 (1), 38-45.

Scheraga, C. (2004). Operational efficiency versus financial mobility in the global airline industry: A data envelopment and TOBIT analysis. Transportation Research Part A, 38, 383-404.

Ulas, E., \& Keskin, B. (2017). Is there a relation between HDI and economic performances?. In New trends in finance and accounting (pp. 61-70). Springer, Cham.

Keskin, B., \& Ulas, E. (2017). Does privatization affect airports performance? A comparative analysis with AHP-TOPSIS and DEA. In New trends in finance and accounting (pp. 335-345). Springer, Cham.

Kopsch, F. (2012). A demand model for domestic air travel in Sweden. Journal of Air Transport Management, 20, 46-48.

Mukkala, K., \& Tervo, H. (2013). Air transportation and regional growth: Which way does the causality run?. Environment and Planning A, 45 (6), 1508-1520.

UsaToday, Retrieved January 21, 2015 from http://www.usatoday.com/story/ todayinthesky/2014/06/05/global-airline-industry-competition-low-cost-carriermiddle-east/10028127/

World Bank, Retrieved December 31, 2015 from www.worldbank.org

Yao, S., \& Yang, X. (2012). Air transport and regional economic growth in China. Asia-Pacific Journal of Accounting \& Economics, 19 (3), 318-329. 